\title{
Correction to: A single-arm feasibility cohort study of rivaroxaban in antiphospholipid syndrome
}

Kimberly Legault ${ }^{1 *}$, Mark Blostein², Marc Carrier ${ }^{3}$, Susan Kahn², Sam Schulman ${ }^{1}$, Sudeep Shivakumar ${ }^{4}$, Cynthia Wu ${ }^{5}$ and Mark A. Crowther ${ }^{1}$

\section{Correction to: Pilot Feasibility Stud 6, 52 (2020) https://doi.org/10.1186/s40814-020-00594-1}

Following publication of the original article [1], the authors opted to correct the last name of co-author Susan Kahn from Khan to Kahn.

\begin{abstract}
Author details
'Department of Medicine, McMaster University, 1280 Main St. W, Hamilton, ON L8S 4L8, Canada. ${ }^{2}$ Department of Medicine, McGill University, 845 Sherbrooke St. W, Montreal, QC, Canada. ${ }^{3}$ Department of Medicine, University of Ottawa, 75 Laurier Ave E, Ottawa, ON, Canada. ${ }^{4}$ Department of Medicine, Dalhousie University, 6299 South St, Halifax, NS, Canada. ${ }^{5}$ Department of Medicine, University of Alberta, 116 St \& 85 Ave, Edmonton, AB, Canada.
\end{abstract}

Published online: 18 May 2020

\section{Reference}

1. Legault K, Blostein M, Carrier M, et al. A single-arm feasibility cohort study of rivaroxaban in antiphospholipid syndrome. Pilot Feasibility Stud. 2020;6:52 https://doi.org/10.1186/s40814-020-00594-1.

The original article can be found online at https://doi.org/10.1186/s40814 020-00594-1.

* Correspondence: legauk2@mcmaster.ca

'Department of Medicine, McMaster University, 1280 Main St. W, Hamilton, ON L8S 4L8, Canada

Full list of author information is available at the end of the article

(c) The Author(s). 2020 Open Access This article is licensed under a Creative Commons Attribution 4.0 International License, which permits use, sharing, adaptation, distribution and reproduction in any medium or format, as long as you give appropriate credit to the original author(s) and the source, provide a link to the Creative Commons licence, and indicate if changes were made. The images or other third party material in this article are included in the article's Creative Commons licence, unless indicated otherwise in a credit line to the material. If material is not included in the article's Creative Commons licence and your intended use is not permitted by statutory regulation or exceeds the permitted use, you will need to obtain permission directly from the copyright holder. To view a copy of this licence, visit http://creativecommons.org/licenses/by/4.0/. The Creative Commons Public Domain Dedication waiver (http://creativecommons.org/publicdomain/zero/1.0/) applies to the data made available in this article, unless otherwise stated in a credit line to the data. 